факти, коментарі. 2018. № 10. - Режим доступу : http://nbuviap.gov.ua/ images/ukraine/2018/ukr9.pdf.

4. Осацька Ю. С., Зінченко О. М. Міжнародна торгівля: сучасний стан та перспективи розвитку. Молодий вчений. 2016. Вип. 12.

DOI https://doi.org/10.30525/978-9934-26-040-7-60

\title{
ОКРЕМІ ПИТАННЯ ТЛУМАЧЕННЯ ТА ІМПЛЕМЕНТАЦІї СТАТТІ 20(2) МІЖНАРОДНОГО ПАКТУ ПРО ГРОМАДЯНСЬКІ ТА ПОЛІТИЧНІ ПРАВА
}

\author{
Коруц У. 3. \\ кандидат юридичних наук, дочент, \\ начальник відділу міжнародних зв'язків \\ Західноукраїнського начіонального університету \\ м. Тернопіль, Украӥна
}

Об'єктом та метою міжнародного права в галузі прав людини часто розуміють захист індивідуальних та колективних прав людини та підтримку та просування ідеалів та цінностей демократичного суспільства. Цей акцент сприяв розвитку інтерпретації положень міжнародних документів про права людини з метою відображення розвитку суспільства 3 часом. У зв'язку з цим Міжнародний пакт про громадянські і політичні права від 1966 року (далі по тексту - МПГПП) та інші міжнародні та регіональні договори про права людини були описані як «живі інструменти», які слід тлумачити «з урахуванням сучасних умов», а не розглядати як договори 3 конкретними умовами, визначеними нормами, що панували на момент їх складання чи ратифікації.

У статті 20 МПГПП зазначено:

1. Будь-яка пропаганда війни повинна бути заборонена законом.

2. Будь-який виступ на користь національної, расової чи релігійної ненависті, що являє собою підбурювання до дискримінації, ворожнечі або насильства, повинен бути заборонений законом [1].

У свою чергу стаття 19 МППГПП рекомендує наступне визначення ключових термінів статті 20(2) та статті 4(а) Міжнародної Конвенції про ліквідацію расової дискримінації. 
«Ненависть» - це стан душі, що характеризується як «сильні та ірраціональні емоції зневаги, ворожнечі та відрази по відношенню до цільової групи». «Ворожість» слід розуміти як прояв екстремального стану душі. Хоча термін передбачає стан душі, потрібна дія. Отже, ворожість можна визначити як прояв ненависті - тобто прояв «сильних та ірраціональних емоцій зневаги, ворожнечі та відрази по відношенню до цільової групи».

Чітке, єдине визначення цих термінів не лише забезпечить певність, необхідну для зобов'язання, яке забороняє конкретну поведінку таким чином, але також буде означати, що зобов'язання буде послідовно застосовуватися в юриспруденції.

Відповідно до статті 19 МПГПП вирішальним та відмінним елементом підбурювання, забороненого частиною 2 статті 20 МПГПП та статтею 4(а) МКЛРД, є намір мовця підбурювати інших до дискримінації, ворожості чи насильства. Хоча багато форм мовлення можуть бути образливими та шокуючими, вирішальним фактором повинно бути те, що оратор, який підбурює інших до дискримінації, ворожості чи насильства, має намір не лише поділитися своїми думками з іншими, але й спонукати інших здійснити певні дії, засновані на цих переконаннях, думках чи позиціях [2].

Міжнародні та регіональні механізми не розробили вичерпного визначення поняття «умисел» щодо підбурювання до дискримінації, ворожості чи насильства. Так само, в міжнародному праві та юриспруденції не існує єдиного визначення поняття «умисел» для кримінальних правопорушень. Однак огляд різних визначень умисних кримінальних правопорушень у міжнародних договорах та національному законодавстві показує, що загальним підходом є забезпечення відповідальності за правопорушення, коли оратор діяв зі знанням справи та 3 наміром спричинити об'єктивні елементи злочину [2].

Стаття 19 не пропонує єдиного визначення наміру на підбурювання. Однак ми пропонуємо, щоб визначення «намір підбурювати до дискримінації, ворожості чи насильства» у національному законодавстві включало такі аспекти:

- навмисне прагнення до пропаганди ненависті;

- навмисне прагнення робити захищену групу мішенню на підставі заборонних підстав [2];

Знання наслідків його / iї дій та знання того, що наслідки будуть або можуть відбутися при звичайному перебігу подій. Стаття 19 МПГПП зазначає, що стаття 20(2) МПГПП вимагає від держав заборони підбурювання. Однак ця стаття прямо не обумовлює, що ця заборона повинна бути передбачена кримінальним законодавством. Однак 
стаття 4(а) МКЛРД конкретно вимагає встановлення кримінальної відповідальності за певну поведінку.

Згідно положень статті 19, держави повинні застосовувати різноманітні правові засоби, включаючи цивільні, адміністративні та інші заходи при забороні підбурювання. Застосування кримінальної відповідальності має обмежуватися лише вироками за найтяжчими формами підбурювання. У більшості сучасних випадків це не так; держави криміналізують широкий спектр висловлювань непослідовно та нерівномірно.

Зусилля по боротьбі з негативними наслідками підбурювання (а також менших, серйозних форм «мови ворожнечі») повинні бути частиною всебічної політики, спрямованої на просування як права на свободу вираження поглядів, так і права на свободу від дискримінації. Отже, держави повинні прийняти низку позитивних політичних заходів, які кидають виклик формам упереджень і нетерпимості, прояви яких є забороненими, але типовими у країні. У всіх випадках увагу слід зосереджувати на сприянні подальшому діалогу та взаємодії, а не на придушенні суперечливих точок зору.

Лише там, де це явно необхідно та пропорційно, ці позитивні політичні заходи повинні доповнюватися будь-яким зверненням до обмежувальних правових механізмів для обмеження права на свободу вираження поглядів. Однак будь-які такі обмеження повинні відповідати умовам, що складаються 3 трьох частин відповідно до статті 19(3) МПГПП; тобто:

- вони повинні бути передбачені законом,

- повинні переслідувати законну мету

- повинні бути необхідними та пропорційними щодо цілей, що переслідуються. Державам слід використовувати ті обмеження, які найменше обмежують право на свободу вираження поглядів, наприклад ті, що містяться у цивільному чи адміністративному праві. Держави повинні надати жертвам цілий ряд засобів правового захисту, таких як деліктні вимоги, право на виправлення та право на відповідь [1].

Застосування кримінальних санкцій слід розглядати «як крайній захід, який застосовуватиметься у виключно виправданих ситуаціях, коли немає жодних інших засобів, здатних досягти бажаного захисту особистих прав у суспільних інтересах». Усі такі заходи мають конкретно посилатися на статтю 20 МПГПП і чітко базуватися на заборонах мови ворожості, що становить підбурювання до ворожості, дискримінації чи насильства.

Звернення до кримінального законодавства не повинно бути відповіддю на інциденти підбурювання у випадках, коли менш суворі 240 
санкції мали б досягти такого ж ефекту. Більше того, досвід багатьох юрисдикцій показує, що цивільно-правові та адміністративно-правові санкції більше підходять як відповідь на «підбурювання». Такі санкції також важливі, оскільки вони передбачають залучення та участь жертв та передбачають конкретне відшкодування для них. У той же час, ці санкції слід оцінювати для того, щоб «уникнути ситуації, коли обмеження, спрямовані на захист меншин від жорстокого поводження, екстремізму чи расизму, мають згубний ефект цензора опозиції та окремих голосів, приглушення меншин та посилення домінуючого політичного, соціального та морального дискурсу та ідеології».

\title{
Література:
}

1. Міжнародний пакт про громадянські і політичні права від 16 грудня 1966 року. URL: https://zakon.rada.gov.ua/laws/show/995_043 (дата звернення: 04.02.2021)

2. Рекомендації стосовно тлумачення та імплементації статті 20(2) Міжнародного пакту про громадянські та політичні права. URL: https://www.ohchr.org/Documents/Issues/Expression/ICCPR/Vienna/ CRP7Callamard.pdf

3. Domestic Implementation of the InternationalCovenant on Civil and Political Rights Pursuantto its article 2 para. URL: https://www.mpil.de/ files/pdf1/mpunyb_seibert_fohr_5.pdf

DOI https://doi.org/10.30525/978-9934-26-040-7-61

\section{ПРОБЛЕМА НАЦІОНАЛЬНОЇ ДОКТРИНИ МІЖНАРОДНОГО ПРАВА: ВІЗІЯ ФРАНЦУЗЬКИХ ЮРИСТІВ-МІЖНАРОДНИКІВ}

\author{
Микитенко О. В. \\ аспірант кафедри міжнародного права \\ Львівського начіонального університету імені Івана Франка \\ м. Львів, Украӥна
}

Вступ. Іспанський учений А. Труйоль і Серра, у своїй науковій праці французькою мовою акцентував: «Якщо вірно, що певні течії думки особливо пов'язані з національними філософськими або науковими традиціями, не менш вірно і те, що наука про право народів $\epsilon$ міжнародною не тільки через природу іiі об'єкта, а через обов'язкову 